\title{
The Effect of Menus on EFL Learners' Look-up Processes
}

\author{
Y. Tono, Tokyo Gakugei University, Tokyo, Japan
}

\begin{abstract}
This paper emphasizes the importance of empirical research on dictionary users and, in particular, investigates the effect of the so-called "menu" (a list of definitions at the beginning of a polysemous article) on EFL (English as a Foreign Language) learners' dictionary look-up processes. The menu has been increasingly popular in English learner's dictionaries in Japan, but no empirical evidence has ever shown that it is really effective for reference acts. Two groups of subjects with different levels of reference skills were observed looking up given information in two different types of mini-dictionaries, one with and the other without the menu. The results showed that the menu was not so effective for skilled users, but that it helped the less skilled users find the appropriate information.
\end{abstract}

Keywords: DICTIONARY USER, USER STUDY, DICTIONARY LAYOUT, LEXICOGRAPHY, LEARNER'S DICTIONARY, REFERENCE SKILLS, LOOK-UP PROCESSES, POLYSEMY, PEDAGOGICAL DICTIONARY, EMPIRICAL RESEARCH, MENU, EXPERIMENTAL DESIGN

Opsomming: Die effek van kieslyste op die naslaanprosesse in EVT-aanleerderswoordeboeke. In hierdie artikel word die belangrikheid van empiriese navorsing oor woordeboekgebruikers beklemtoon en word spesifiek die uitwerking van die sogenaamde "kieslys" ('n lys definisies aan die begin van 'n polisemiese artikel) op die naslaanprosesse in EVT(Engels as ' $n$ vreemde taal) aanleerderswoordeboeke ondersoek. Die kieslys het toenemend gewild geword in Engelse aanleerderswoordeboeke in Japan, maar geen empiriese bewyse het nog getoon dat dit werklik doeltreffend is vir naslaanhandelinge nie. Twee groepe proefpersone met verskillende vlakke van naslaanvaardighede is waargeneem terwyl hulle gegewe inligting met behulp van twee verskillende soorte miniwoordeboeke nageslaan het, een met en die ander sonder 'n kieslys. Die resultate het getoon dat die kieslys nie so doeltreffend was vir die ervare gebruikers nie, maar dat dit die minder ervare gebruikers gehelp het om die paslike inligting te kry.

Sleutelwoorde: WOORDEBOEKGEBRUIKER, GEBRUIKSNAVORSING, WOORDEBOEKUITLEG, LEKSIKOGRAFIE, AANLEERDERSWOORDEBOEK, NASLAANVAARDIGHEDE, NASLAANPROSESSE, POLISEMIE, OPVOEDKUNDIGE WOORDEBOEK, EMPIRIESE NAVORSING, KIESLYS, EKSPERIMENTELE ONTWERP 


\section{INTRODUCTION}

The development of second-language lexicography during the last two decades has been remarkable not only in Japan but world-wide. English pedagogical dictionaries in Japan used to be compiled on the basis of British and American lexicographical traditions. However, since we realized the importance of information unique to our language-learning environments, our goal has shifted from mere translation of European dictionaries to more culture-specific and learner-centred dictionary-making.

The publication of new dictionaries has encouraged more innovative ideas in terms of information categories and dictionary layout. Today, without something new, the product will not command attention. Dictionaries have become increasingly sophisticated tools, designed for skilled users, while no remedial work has been done for users with poor skills. Some lexicographers have therefore focussed our attention on the growing gap between the sophistication of dictionaries and the users' rudimentary reference skills. See, for example, Cowie (1983: 136).

While there are a great many EFL dictionaries in Japan, almost no research has been done in connection with dictionary users and their skills. The same can be said of lexicography in other countries. Until a decade ago, lexicographers compiled dictionaries according to their expectations about what users want to find in a dictionary and not according to what they really need.

Dictionaries in many countries still cling to the authoritarian tradition and their value and usefulness have hardly been questioned. The dictionary user has often been ignored and very little effort has been made to find out what the dictionary user does and why he behaves the way he does. It should be kept in mind that the purpose of lexicography is not only to describe words systematically, but also to produce a lexicographical output which should have practical utility. Therefore, we should seriously ask ourselves the following questions: Does the dictionary really meet users' needs and do the users actually utilise the information which the lexicographers thought was necessary? Empirical data on users' reference needs and skills is definitely necessary if we want to develop truly user-friendly dictionaries. At the same time, what the lexicographer believes to be innovative should be empirically tested. As in other areas of science, basic and applied research should go hand in hand. Such fundamental research and its application will contribute to a better lexicographical output and overall theory-construction.

In this paper, one of the recently highlighted dictionary-layout devices called a "menu" will be discussed as an example of dictionary-user research and its effect will be empirically tested. In Section 2 previous research will briefly be reviewed; in Section 3 the design of the present research will be specified; and in Section 4 the research findings will be discussed. 


\section{REVIEWS}

\subsection{Research methods in dictionary-user study}

Fundamental questions in dictionary-user study are: How do dictionary users conduct their look-up processes and why do they behave in a specific way? The answer to the first question implies a descriptive statement and the answer to the second implies a causal statement. The researcher, for instance, wants to ascribe dictionary users' poor reference skills to a lack of look-up training, the poor quality of dictionaries, etc.

In order to investigate these various aspects concerning dictionary users, we need to know the relevant research tools and their application. Unfortunately, not many lexicographers are versed in this kind of research methodology. This is quite natural, for it is not lexicographers themselves but psychologically-oriented metalexicographers who can best deal with this aspect of dictionary study.

In scientific study, a phenomenon is described, explained, and predicted; and each of these actions involves the following terms: observation, correlation, and experimentation. If we review the dictionary-user research done so far according to these three methods, it will show how much we are in need of experiments.

\subsection{Descriptive studies}

\subsubsection{Historical research}

The history of lexicography has been a major area of interest for decades, but it was not until recently that the importance of the user perspective was realised with regard to historical research. In 1987, Hartmann (1987a: 122) stressed that "a history of dictionary use is ... urgently needed". He suggested that the history of lexicography should incorporate more knowledge about the benefits dictionaries brought to their users.

\subsubsection{Surveys}

Probably the most widely used research method with regard to the dictionary user is the survey. Generally, surveys deal with the incidence, distribution and relationships of educational, psychological, and sociological variables (Wiersma 1991: 16). All variables are studied ex post facto, that is, as they exist in the situation. No experimental variables are manipulated. Furthermore, most of the surveys on dictionary-users' study are limited to describing the status quo. 
Table 1 summarizes the major survey results:

Table 1. Selected dictionary-user surveys

\begin{tabular}{|c|c|c|c|c|}
\hline Researcher & Type of User & $\mathrm{n}=$ & Technique & Main findings \\
\hline $\begin{array}{l}\text { C. Bamhart } \\
\text { (1962) }\end{array}$ & $\begin{array}{l}\text { U.S. college } \\
\text { students }\end{array}$ & 108 & Questionnaire & $\begin{array}{l}\text { Priority: } \\
\text { (1) meaning } \\
\text { (2) spelling } \\
\text { (3) pronunciation } \\
\text { (4) synonyms } \\
\text { (5) usage } \\
\text { (6) etymology }\end{array}$ \\
\hline $\begin{array}{l}\text { R. Quirk } \\
\text { (1973) }\end{array}$ & $\begin{array}{l}\text { British univer- } \\
\text { sity students }\end{array}$ & 220 & Questionnaire & $\begin{array}{l}\text { High rates of owmer- } \\
\text { ship and frequent use; } \\
\text { meaning as chief } \\
\text { reason for dictionary } \\
\text { consultation }\end{array}$ \\
\hline $\begin{array}{l}\text { J. Tomaszczyk } \\
\text { (1979) }\end{array}$ & $\begin{array}{l}\text { Various foreign } \\
\text { language } \\
\text { learners }\end{array}$ & 449 & Questionnaire & $\begin{array}{l}\text { Use of dictionary } \\
\text { depends on nature of } \\
\text { activity and } \\
\text { proficiency levels }\end{array}$ \\
\hline $\begin{array}{l}\text { H. Béjoint } \\
\text { (1981) }\end{array}$ & $\begin{array}{l}\text { French university } \\
\text { students of } \\
\text { English }\end{array}$ & 122 & Questionnaire & $\begin{array}{l}\text { Language learners do } \\
\text { not utilize all } \\
\text { information offered } \\
\text { in dictionary }\end{array}$ \\
\hline $\begin{array}{l}\text { R. Hartmann } \\
\text { (1983a) }\end{array}$ & $\begin{array}{l}\text { British teachers } \\
\text { and leamers of } \\
\text { German }\end{array}$ & $\begin{array}{l}67 \\
118\end{array}$ & Questionnaire & $\begin{array}{l}\text { Meaning and grammar } \\
\text { most important need } \\
\text { (for translation) }\end{array}$ \\
\hline $\begin{array}{l}\text { B.T. A tkins, } \\
\text { et al. (1987) }\end{array}$ & $\begin{array}{l}\text { EFL learners in } \\
\text { seven countries }\end{array}$ & 1100 & $\begin{array}{l}\text { Questionnaire } \\
\text { and other tasks } \\
\text { identified }\end{array}$ & $\begin{array}{l}\text { Various needs and } \\
\text { skills characteristics }\end{array}$ \\
\hline
\end{tabular}


Barnhart (1962) probably made the first attempt at quantifying our knowledge about the purposes and roles of the dictionary. 108 questionnaires were sent out to teachers of English composition classes, asking them to rate six types of information commonly offered in American college dictionaries according to the importance attached to them by freshmen students. The findings showed that, in order of priority, they regarded meaning, followed by spelling, pronunciation, synonyms, usage and etymology as the most important information types. Barnhart's paper was of considerable interest to lexicographers having to decide what kind of material should be included in a dictionary.

In spite of many interesting and useful comments, Bamhart's paper was not scientifically well motivated. Furthermore, his survey could not be replicated because he did not reproduce his questionnaire and numerical results. This made a follow-up study basically impossible.

Quirk (1973) attempted to assess the attitudes, expectations, and prejudices of dictionary users. "The focus was no longer on the producer of the dictionary and its potential appeal to an anonymous market," Hartmann (1987a: $127)$ commented, "but on the opinions of real users." Quirk did specify his survey method and numerical data, which rendered greater validity to his research. See also Crystal (1986).

Tomaszczyk (1979) investigated the dictionary requirements of the foreign-language learner and translator. 449 people completed his questionnaire. He found that the amount of dictionary use depends on the nature and extent of the activity. Again, however, the questionnaire was not reproduced and the problem of replicability arises again.

Bejoint (1981) also used the questionnaire to examine the language needs and reference skills of 112 French students of English at the University of Lyon. He prepared 21 questions for his questionnaire, but did not specify the purpose of each question, so that the results did not clearly show how the reference skills had been investigated.

Hartmann (1983a) did research on learners of German in South West England. He found that bilingual dictionaries were so commonly used within and outside formal language classes and that monolingual dictionaries are so under-developed in languages other than English, that it would be very hard to 'wean away' the learner from the translation dictionary. He also found that grammar and meaning were the most important requirements for translation. This partly confirms the findings of Tomaszczyk (1979) and Béjoint (1981).

Admitting the value of these surveys, we have to guard against the pitfalls in this type of research. Since they all comprise indirect surveying, the evidence may not reflect the subjects' real behaviour. It often happens that participants, instead of responding naturally, respond in ways they think the research demands, which leads to inaccurate interpretation of the data. "More and more the suspicion is gaining ground," Hartmann (1987b: 15) mentions, "that indirect surveying of population samples needs to be supplemented or replaced by more carefully controlled direct observation." 
The most comprehensive and systematic survey to date is the research project on the use of learner's dictionaries conducted by Beryl T. Atkins et al. The first preliminary report was given in Cowie (1987). It was followed by a detailed study in which the use of dictionaries by students of English as a foreign language, namely native speakers of French, German, Italian and Spanish, was investigated. Over 1100 responses from seven countries were received. The survey consisted of the Dictionary-user Profile Form, the Placement Test, and the Dictionary Research Test. The results are now available in the EURALEX database. It is an excellent piece of research which provides us with many insights and interesting research questions. More of this type of descriptive study is definitely needed to improve the quality of correlational and experimental approaches.

\subsubsection{Direct observation}

In order to capture authentic data the questionnaire should be supplemented with exercises, interviews and tests. For example, Ard (1982) combined filmed protocols with oral interviews to observe the effect of bilingual dictionaries on ESL writing tasks. The design itself was interesting though the sample (just two) was too small to make any generalizations. Experiments with small examples need to have either many different levels of independent variables or the related variables must be very strictly manipulated and controlled (Elmes, et al. 1981: 125).

Krings (1986) used so-called thinking-aloud protocols to record the psycholinguistic complexities of the translation process. This approach is very widely used in psychological research. Tono (1991) also observed the look-up behaviour of the good dictionary user. Recordings were made of the time taken for specific reference acts. The data on the degree of difference between good and poor dictionary users in a particular task was described in detail. This kind of approach, that is, a large number of observations made upon a small number of subjects, will also be promising in investigating the nature of the user's reference skills.

\subsection{Correlational studies}

Very few correlational studies have so far been conducted on the dictionary user. Quirk (1973) and Hartmann (1983a) attempted statistical correlations of their data, but their research interests and designs do not fit this category. In Israel, Marsha Bensoussan et al. (1984) investigated the relationship between reading comprehension and the use of dictionaries. The results of several empirical tests with some 700 Israeli EFL university students led to the conclusion that the use of the dictionary has no significant effect on reading 
comprehension test scores. Furthermore, it makes no difference whether a monolingual or bilingual dictionary is used. Nor does the use of a dictionary affect the time needed to complete the test. Although the sample was quite large, there are doubts as to whether all the confounding variables were properly controlled. For example, the level of the task and its mode of assessment may have been too artificial or inappropriate when we consider the proficiency level of the subjects - advanced learners in this case.

While Bensoussan et al. (1984) investigated the static relation between dictionary use and reading comprehension, Tono (1988) was interested in the dynamic, developmental nature of dictionary skills and its relation to reading ability. Although the results were still inconclusive, he discovered that a significant difference in performance exists between reading comprehension with and without dictionaries, and that continuous dictionary use has a positive effect on the development of reading ability.

\subsection{Experimental studies}

An experiment is conducted when the environment is systematically manipulated in order to observe the effect of this manipulation on some kind of behaviour. Experiments are very cogent because, while non-experimental research techniques are limited to statements about correlation, experiments permit statements about causation - that is, independent variable A causes dependent variable $B$ to change.

In dictionary-user study, it is essential not only to describe the behaviour of dictionary users, but also to explain the cause of their behaviour. In order to accomplish this, experiments are necessary. Hartmann (1987a, 1987b, 1988, 1989) has been putting special emphasis on the need for experimental research, but still very few attempts have been made.

Tono (1984) may be among the first who conducted controlled experiments on dictionary users. In order to investigate the parameters of dictionary look-up, 402 randomly selected students were tested on a translation task. The English passages contained a number of artificial words which were illustrated and explained in mini-dictionaries, carefully controlled for definition styles and the ordering of examples. Since the present study depends on these findings, this research will be discussed in more detail.

Suppose the subject comes across sentence (1) which contains an artificial word beduck and looks up the word in the minidictionary which provides the information in (2):

(1) I beducked his family of his death.

（2） beduck（vt.） 1 (物事を) (人に）報告する、通知する（to inform） 2 (物事を)（人に）確認する (to make sure) 
The subject will have difficulty in deciding which meaning is appropriate for its translation equivalent. In Japanese, both meanings in (2) make perfect sense in this sentence. Therefore, the subject may choose either of them unless some other clues are available. Compare it with the following:

\section{（3） beduck（vt.） 1 (物事を）（人に）確認する、通知する（(of ...))

In this case, the collocational information ((of...)), if the subject really uses it, will help him pick out the first rather than the second definition.

Tono invented two kinds of mini-dictionaries, one with information as in (3) and the other without such information. These different types of dictionaries were given to the subjects in their translation task and the subjects' choices of the definitions were recorded so as to see how the subjects used the information provided in the mini-dictionaries. The following seven types of information were selected to see if the subjects used them properly:

(4) (a) grammatical information

(b) verb pattern

(c) countable vs. uncountable

(d) gloss

(e) collocation

(f) idiom

(g) run-on

Besides the information categories in (4), Tono investigated the effect of illustrative examples and the definition order.

Statistical analysis of the data confirmed the hypothesis that users (at least of bilingual English-Japanese dictionaries) tend to choose the translation equivalent that appears as the first sub-entry and ignore definitions and examples in subsequent sub-entries unless there is an obvious negative clue which makes the initial sense unlikely. Figure 1 illustrates this process.

The results show that the skilled users employ semantic and grammatical information equally well, but that the poor users rely heavily on semantic information. If the first definition fits in the context, it will be chosen. Other information such as collocation, countable/uncountable, verb pattern, etc. is hardly used in a positive way to select appropriate definitions.

Tono (1984) also found that if the entry had a long list of examples after the first definition, the subjects were discouraged to go over to the second definition. This is why Tono suggested that the menu system, a list of senses without examples and detailed information, should be put at the beginning of each multiple entry. 
Figure 1. The dictionary look-up process based on Tono (1984)

Find appropiate headword YES

Look at first definition

YES

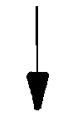

Does the meaning fit in the context?

YES

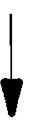

Is the user heavily meaning-dependent?

YES

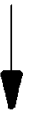

Choose this definition

Some users give it up here because of too long illustrative examples under first definition
Note: If the users are more skilled, they may not look at sub-entries one at a time. They would rather scan the whole entry. 
As a matter of fact, after this research had been conducted, many English-Japanese dictionaries adopted this menu system as an innovative device. Figure 2 shows samples of the menu systems in some popular English-Japanese dictionaries. Nowadays, more than one third of all the English-Japanese pedagogical dictionaries contain the menu. In spite of its popularity, very little empirical investigation has been done on menu effect.

Figure 2. Samples of the menu systems in some English-Japanese dictionaries

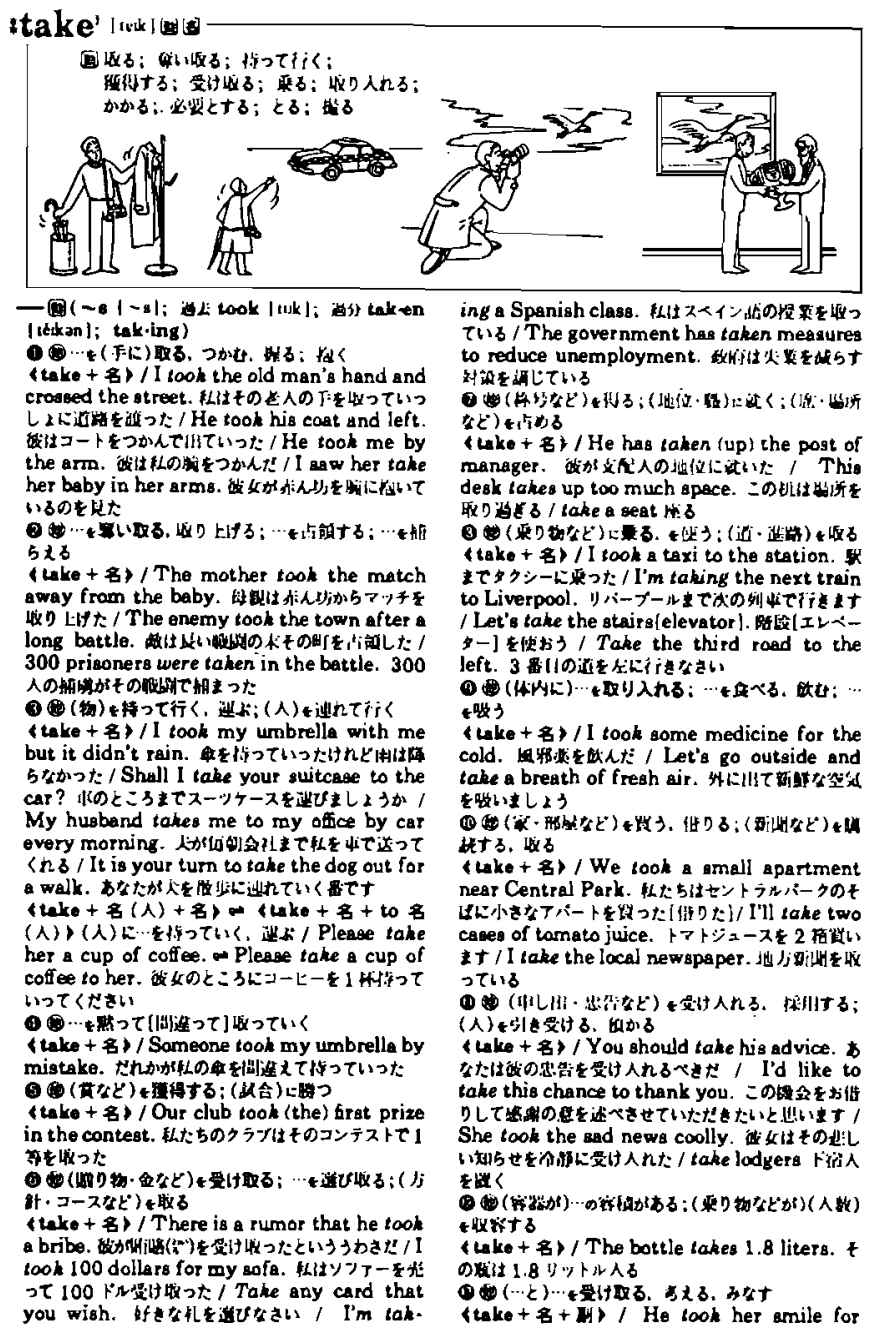




\subsection{Summary}

Thus far an overview has been given of the development of research methods in the field of user study and the need for more empirical data has been emphasized, especially that based on experimental designs. Tono (1984) shed light on the possibility of empirical research supporting more realistic and data-based, user-friendly dictionary making. Let us now consider scientifically exploring the effect of dictionary layout, particularly the menu, on the user's reference act.

\section{METHOD}

\subsection{Hypothesis}

In the last section, we observed the limited reference skills of dictionary users and the potential of the menu for helping them. Many recent English-Japanese learner's dictionaries have adopted the menu for basic words, but its effect has never been tested. We would like to see if the menu really works, in other words, helps the users find the appropriate definition in spite of their limited experience of dictionary use.

For the sake of the experiment, the following null hypotheses were tested:

(1) (a) The menu group and the non-menu group do not differ with regard to the time and effort spent on obtaining the appropriate information (in this case, for recognition purposes).

(b) The menu effect and the level of reference skills are independent.

The corresponding alternative hypotheses are:

(2) (a) The menu group is able to find the appropriate information more easily than the non-menu group.

(b) The menu is effective only for those who have limited reference skills.

In other words, the independent variables for this study were the presence or absence of the menu, and the user's levels of reference skills. The dependent variables were the ease with which the users found the appropriate information in the dictionary. The details of the experiment are described in the following sections. 


\subsection{Subjects}

57 first-year students, majoring in law at Keio University, and 182 third-year students from Setagaya Junior High School attached to Tokyo Gakugei University participated in this study. These two groups were chosen because they represented different levels of dictionary skills. The Keio University students had had a great deal of experience in dictionary use, for they had to prepare for the college entrance examination. On the other hand, the Setagaya Junior High School students are taught according to the communicative approach in which dictionaries are not extensively used. The difference in the levels of English proficiency, however, was not so serious a problem, because the English sentences to be translated into Japanese in this. study were not too difficult for junior high school students.

\subsection{Instruments}

A special test was developed to facilitate this study. The test consisted of nine English sentences, each of which contained one artificial word. The subjects were asked to translate the sentences into Japanese, using the attached minidictionaries. Two types of dictionaries were used: one with and the other without the menu. Artificial words were inserted into each sentence to ensure that all the subjects look up the same words and to control the information regarding the artificial words. In the case of (3) the artificial word stup was inserted:

(3) If you say something like that, I'm sure he will be stup about it.

Suppose we invented two different definitions for the word stup such as the following:

(4) (a) sorry

(b) angry

We cannot tell which definition is correct in (3) unless some other contextual clues are provided.

The word stup, however, would mean "angry" if the following collocational information were given in the dictionaries:

(5) (a) sorry ((of))

(b) angry ((about))

In this case, the subjects should choose the second definition "angry" as the correct one, if they actually use the collocational information ((about)). (b) is therefore the correct answer, and (a) the wrong answer. 
Our goal is to determine whether this reference process is facilitated more effectively when the menu is provided at the beginning of each entry. If the menu does facilitate the look-up process, the subjects who use the menu-containing dictionaries should be able to choose the appropriate definitions with greater ease than those who use the dictionaries without the menu. As mentioned in Section 2, Tono (1984) found that many dictionary users had difficulty in proceeding from the first definition (polysemic meaning) to the second. Tono (1984) predicted that a menu system would assist the users, and some other scholars pointed out that this is an interesting possibility (Hartmann 1988, 1989; Ripfel 1988). Present research aims at verifying this.

For further details of the test and the mini-dictionaries, see Appendices A and $\mathrm{B}$.

\subsection{Design}

Ideally, the selection of the experimental group and the control group should be based on the results of a pretest on dictionary-using skills. However, as it is very time-consuming to form a reliable and valid dictionary-skills battery, we chose economy rather than control. Moreover, by selecting homogeneous groups (i.e. college students and junior high school students), we believe that the two different levels of the independent variable (i.e. the dictionary-using skills) were fixed. As will be seen later, about ten percent of the junior high school students did not succeed in completing the tests in time, which shows that there was a slight proficiency effect on the test, although the overall picture of the results was not influenced by this variable. Therefore, while we are confident that our results are quite reliable and valid, the reader is advised to regard this study as quasi-experimental. A more controlled experiment might yield slightly different results.

\subsection{Procedure}

The test was conducted at the beginning of the class as part of the regular class activities. The teacher provided one half of the class with the dictionaries containing the menu and the other half with the dictionaries without the menu. The teacher did not mention the fact that there were artificial words in the test and that two different dictionaries were distributed. Instead, the teacher asked the class to translate the sentences into Japanese and told them that there were some difficult words and that the meanings were given in the mini-dictionaries. The time allowed for the test was fifteen minutes. 


\subsection{Data analysis}

Each test was checked to see which definitions were chosen. The accuracy of the translation was ignored, and only the choices of the definitions for the artificial words were considered. The results, i.e. the definitions chosen, were recorded for both the menu group and the non-menu group. Since this variable was a nominal scale, a chi-square test was used to show the differences in the choice of the definitions.

\section{RESULTS AND DISCUSSION}

The test results are shown in Tables 2 and 3. In the case of the junior high school students (see Table 2), there was a significant difference between the menu group and the non-menu group in the choice of the appropriate definitions. In comparison with the non-menu group, the menu group had chosen the meaning correctly in seven out of nine sentences. This means that, with the help of a menu in their dictionaries, the junior high school students found the necessary information more effectively.

Table 2. Choice of definitions (junior high school students, $\mathbf{n}=182$ )

\begin{tabular}{|c|c|c|c|c|c|c|c|}
\hline & \multirow{2}{*}{$\begin{array}{l}\text { WORD } \\
\text { INFOR- } \\
\text { MATION }\end{array}$} & \multirow{2}{*}{$\begin{array}{l}\text { DOES THE } \\
\text { DICT. HAVE } \\
\text { THE MENU? }\end{array}$} & \multicolumn{4}{|c|}{ CHOICE OF DEFINITIONS } & \multirow{2}{*}{$\left(p^{x^{2}} .01\right)$} \\
\hline & & & RICHT & WRONC & OTHER & TOTAL & \\
\hline \multirow{2}{*}{ (1) } & Atup & YES & 68 (90x) & $4(5 x)$ & $4(5 x)$ & 76 & \multirow{2}{*}{$33.79=$} \\
\hline & collo. & No & $37(49 x)$ & $35(46 x)$ & $4(5 x)$ & 76 & \\
\hline \multirow{2}{*}{ (2) } & dondlo & res & $43(57 x)$ & $18(24 x)$ & $15(19 x)$ & 76 & \multirow{2}{*}{.50} \\
\hline & vt/ vi & MO & $40(53 x)$ & $22(29 x)$ & $14(184)$ & 76 & \\
\hline \multirow{2}{*}{ (3) } & gollapo & YES & $68(90 x)$ & $4(5 x)$ & $4(5 x)$ & 76 & \multirow{2}{*}{$4.50^{-}$} \\
\hline & $\{\mathrm{U}] /[\mathrm{c})$ & No & $60(79 x)$ & $12(16 x)$ & $4(5 x)$ & 76 & \\
\hline \multirow{2}{*}{ (4) } & collugo & YES & $28(37 x)$ & $37(49 x)$ & $3(4 x)$ & 76 & \multirow{2}{*}{.02} \\
\hline & vt/ $\mathbf{v i}$ & NO & $30(10 x)$ & $39(5 \mid x)$ & 7 (9x) & 76 & \\
\hline \multirow{2}{*}{ (s) } & placter & YES & $16(21 x)$ & $48(63 x)$ & $12(16 x)$ & 76 & \multirow{2}{*}{$6.50^{\circ}$} \\
\hline & (U) $/[\mathrm{C}]$ & No & $s(7 x)$ & 37 (75x) & $14(18 x)$ & 76 & \\
\hline \multirow{2}{*}{ (6) } & seralo & YES & $59(78 x)$ & $10(13 x)$ & ? (ax) & 76 & \multirow{2}{*}{$4.46^{\circ}$} \\
\hline & gloes & No & $48(63 x)$ & $20(26 x)$ & $8(11 x)$ & 76 & \\
\hline \multirow{2}{*}{ (7) } & teraus & YES & $s(7 x)$ & $60(79 x)$ & $11(14 x)$ & 76 & \multirow{2}{*}{$7.78^{\circ}$} \\
\hline & {$[u] /[c]$} & No & $16(21 x)$ & $45(59 x)$ & $25(20 x)$ & 76 & \\
\hline \multirow{2}{*}{ (8) } & boduck & YES & $24(32 x)$ & $52(68 x)$ & $0(0 x)$ & 76 & \multirow{2}{*}{$5.05^{-}$} \\
\hline & $v t / v i$ & No & $12(16 x)$ & $63(83 x)$ & $1(1 x)$ & 76 & \\
\hline \multirow{2}{*}{ (9) } & ACtOAs- & YES & $71(93 x)$ & $5(7 x)$ & $0(0 \mathbf{x})$ & 76 & \multirow{2}{*}{$16.02^{\circ}$} \\
\hline & $\operatorname{col} 10$. & NO & So $(66 \mathbf{x})$ & $24(32 x)$ & $2(2 \mathbf{x})$ & 76 & \\
\hline
\end{tabular}


Table 3. Choice of definitions (first-year college students, $n=57$ )

\begin{tabular}{|c|c|c|c|c|c|c|c|}
\hline & \multirow{2}{*}{$\begin{array}{l}\text { WORD } \\
\text { INFOR- } \\
\text { MATION }\end{array}$} & \multirow{2}{*}{$\begin{array}{l}\text { DOES THE } \\
\text { DICT. HAVE } \\
\text { THE MENU? }\end{array}$} & \multicolumn{4}{|c|}{ CHOICE OF DEFINITIONS } & \multirow{2}{*}{$(0<.01)$} \\
\hline & & & RIGHT & WRONG & OTHER & TOTAL & \\
\hline \multirow{2}{*}{ (1) } & \multirow{2}{*}{$\begin{array}{l}\text { stup } \\
\text { collo. }\end{array}$} & YES & $28(97 x)$ & $1(3 x)$ & & 30 & \multirow{2}{*}{2.34} \\
\hline & & NO & $23(85 x)$ & $4(19 x)$ & & 27 & \\
\hline \multirow{2}{*}{ (2) } & \multirow{2}{*}{$\begin{array}{l}\text { dondle } \\
\mathrm{ve} / \mathrm{vi}\end{array}$} & YES & $27(90 x)$ & $3(10 x)$ & & 30 & \multirow{2}{*}{.37} \\
\hline & & NO & $22(81 x)$ & $4(15 x)$ & $1(\mathbf{4 x})$ & 27 & \\
\hline \multirow{2}{*}{ (3) } & \multirow{2}{*}{$\begin{array}{l}\text { poltago } \\
{[U] / ! C !}\end{array}$} & YES & $29(97 x)$ & $c(0 x)$ & $1(3 x)$ & 30 & \multirow{2}{*}{1.09} \\
\hline & & NO & $26(96 x)$ & $1(4 x)$ & & $2 ?$ & \\
\hline \multirow{2}{*}{ (4) } & \multirow{2}{*}{$\begin{array}{l}\text { colluge } \\
\mathrm{vt} / \mathrm{vi}\end{array}$} & YES & $18(60 x)$ & $12(40 x)$ & & 30 & \multirow{2}{*}{.81} \\
\hline & & NO & $13(48 x)$ & $14(52 x)$ & & 27 & \\
\hline \multirow{2}{*}{ (s) } & \multirow{2}{*}{$\begin{array}{l}\text { plactar } \\
\text { [Ul/CC] }\end{array}$} & YFS & $10(33 x)$ & $20(67 x)$ & & 30 & \multirow{2}{*}{.04} \\
\hline & & NO & 8(29x) & $18(67 x)$ & $1(4 x)$ & 27 & \\
\hline \multirow{2}{*}{ (6) } & \multirow{2}{*}{$\begin{array}{l}\text { acrata } \\
\text { gloes }\end{array}$} & YES & $25(83 x)$ & $s(17 x)$ & & 30 & \multirow{2}{*}{1.03} \\
\hline & & NO & $16(67 x)$ & $7(26 x)$ & $2(7 \pi)$ & 27 & \\
\hline \multirow{2}{*}{ (7) } & \multirow{2}{*}{$\begin{array}{l}\text { toraue } \\
{[U] /[C]}\end{array}$} & YES & B (27x) & $22(13 x)$ & & 30 & \multirow{2}{*}{.15} \\
\hline & & NO & $6(22 x)$ & $21(78 x)$ & & 27 & \\
\hline \multirow{2}{*}{ (B) } & \multirow{2}{*}{$\begin{array}{l}\text { beduck } \\
\text { ve/ui }\end{array}$} & YES & $16(53 x)$ & $14(17 x)$ & & 30 & \multirow{2}{*}{1.05} \\
\hline & & NO & $18(67 x)$ & $9(33 x)$ & & 27 & \\
\hline \multirow{2}{*}{ (9) } & \multirow{2}{*}{$\begin{array}{r}\text { actase- } \\
\text { Ing } \\
\text { collo. }\end{array}$} & YES & $30(100 x)$ & $0(0 x)$ & & 30 & \multirow{2}{*}{1.13} \\
\hline & & No & $26(96 x)$ & $1(4 x)$ & & 27 & \\
\hline
\end{tabular}

On the other hand, there was no significant difference between the two groups of college students (see Table 3). This indicates that for the college students the menu was not so useful in helping them find the appropriate information.

Let us take a closer look at each item. In the translation of the sentences containing the artificial words dondle and colluge there was no significant difference between the junior high school students and the college students provided with the menu and those without the menu. In the case of dondle and beduck most of the college students and fifty percent of the junior high school students chose the appropriate definitions. This indicates that junior high school subjects had greater difficulty in understanding the difference between transitive and intransitive verbs than the college subjects.

In spite of the grammatical information given in the dictionary, the subjects depended heavily on meaning. For example, in the case of foltage, most subjects chose "good result" instead of "influence". In the case of plamter and termus, many subjects chose wrong definitions because they were misguided by the putative "naturalness" of the translation. Even though the grammatical information was given and the menu was provided, the subjects were very much concemed whether the meaning fits the context. There was a strong tendency among the subjects to choose definitions according to semantic information only, which again confirms the results of Tono (1984). 
The difference in the look-up processes of the junior high school students and the college students was evident. Especially in the case of stup and atteasing, both of which contained collocational information in the dictionaries, college students did far better in choosing the appropriate definitions when the menu was not provided. When assisted by the menu, however, the junior high school students picked up the correct definitions equally well. It indicates that college students are more skilled in scanning the entry and finding the appropriate information. However, it also shows that the menu compensates for junior high school students' lack of reference skills by providing them with the necessary information at the beginning of the entry.

Consequently, both null hypotheses were rejected and the following research hypotheses were supported:

(1) users who have the menu in their dictionaries are able to find the given information more easily than those who have no menu.

(2) (1) is true only for the users with limited reference skills. Skilled users utilize the menu less.

\section{CONCLUSIONS}

The menu proves to be an effective aid for poor dictionary users. Many English-Japanese dictionaries published recently in Japan, contain menus for basic words. Their primary target is junior and senior high school students. Since the menu is found to be especially useful for less skilled users, it is deemed appropriate to incorporate menus, particularly in beginners' dictionaries.

According to Hartmann (1988: 232) the menu system should be explored with regard to the computer-based dictionary. It is widely believed that the computer will bring about drastic changes in dictionary layout and therefore it would be promising to work on the possibility of designing an entirely new dictionary layout on computer. Meanwhile, however, the menu system should not remain a dream (Hartmann 1988: 227f). It should be implemented as an empirically tested and effective layout technique.

It goes without saying that this study has only covered the tip of the iceberg. Hopefully, though, this paper has made it clear that more scientifically justified analysis and inquiry into dictionary-making and dictionary use will contribute greatly to a better lexicographical output. 


\section{REFERENCES}

\section{Dictionaries}

Konishi, T., M. Yasui, T. Kunihiro and K. Horiuchi (Eds.). 1992. Shogakukan Learmet's Progressive English-Japanese Dictionary. (Learner's Progressioe). Tokyo: Shogakukan.

Nakamura, K. (Ed.). 1986. First English-Japanese Dictionary. (First). Tokyo: Sanseido.

Shibata, T., H. Hatori and T. Wright. (Eds.). 1985. Junior Anchor English-Japanese Dictionary. (Junior Anchor). Tokyo: Gakken.

Takebayashi, S. and Y. Kojima (Eds.). 1990. Kenkyusha's Lighthouse English-Japanese Dictionary. Second Edition. (Lighthouse). Tokyo: Kenkyusha.

\section{Other sources}

Ard, J. 1982. The Use of Bilingual Dictionaries by ESL Students while Writing. International Review of Applied Linguistics 58: 1-27.

Atkins, B.T., H. Lewis, D. Summers and J. Whitcut. 1987. A Research Project into the Use of Leamer's Dictionaries. Cowie, A.P. (Ed.). 1987: 29-43.

Barnhart, C.L. 1962. Problems in Editing Commercial Monolingual Dictionaries. Householder, F.W. and S. Saporta (Eds.). 1962: 161-181.

Béjoint, H. 1981. The Foreign Student's Use of Monolingual English Dictionaries: A Study of Language Needs and Reference Skills. Applied Linguistics 2: 207-222.

Bensoussan, M., D. Sim and R. Weiss. 1984. The Effect of Dictionary Usage on EFL Test Performance compared with Student and Teacher Attitudes and Expectations. Reading in a Foreign Language 2: 262-276.

Cowie, A.P. 1983. The Pedagogical/Learner's Dictionary. Hartmann, R.R.K. (Ed.), 1983b: 135-143.

Cowie, A.P. (Ed.). 1987. The Dictionary and the Language Leamer. Tübingen: Max Niemeyer Verlag. Crystal, D. 1986. The Ideal Dictionary, Lexicographer and User. Ilson, R.E. (Ed.). 1986: 72-81.

Elmes, D.G., B.H. Kantowits and H.L. Roediger III. 1981. Methods in Experimental Psychology. Boston: Houghton Mifflin.

Hartmann, R.R.K. 1983a. The Bilingual Learner's Dictionary and its Uses. Multilingua 2: 195-201.

Hartmann, R.R.K. (Ed.). 1983b. Lexicography: Principles and Practice. London: Academic Press.

Hartmann, R.R.K. 1987a. Dictionaries of English: The User's Perspective. Bailey, Richard W. (Ed.). 1987. Dictionaries of English: Prospects for the Record of Our Language: 121-135. Ann Arbor: The University of Michigan Press.

Hartmann, R.R.K. 1987b. Four Perspectives on Dictionary Use: a Critical Review of Research Methods. Cowie, A.P. (Ed.). 1987: 11-28.

Hartmann, R.R.K. 1988. The Leamer's Dictionary. Traum oder Wirklichkeit. Hyldgaard-Jensen, K. and A. Zettersten (Eds.). 1988. Symposium on Lexicography III: 215-236. Tübingen: Max Niemeyer Verlag. 
Hartmann, R.R.K. 1989. Sociology of the Dictionary User: Hypothesis and Empirical Studies. Hausmann, F.J. et al. (Eds.). 1989. An International Encyclopedia of Lexicography I: 102-111. Berlin: Walter de Gruyter.

Hausmann, F.J. 1986. The Training and Professional Development of Lexicographers in Germany. Ilson, R.E. (Ed.). 1986: 101-110.

Householder, F.W. and S. Saporta 1962. Problems in Lexicography. Bloomington: Indiana University Press.

Ilson, R.E. (Ed.). 1986. Lexicography: An Emerging International Profession. The Fulbright Papers I. Manchester: Manchester University Press.

Krings, H.P. 1986. Was in den Köpfen von Übersetzern vorgeht. Eine empirische Studie zur Struktur des Übersetzungsprozesses an fortgeschrittenen Französischlemem. Tübingen Beiträge zur Linguistik: 291. Tübingen.

Quirk, R. 1973. The Social Impact of Dictionaries in the UK. McDavid, R.l. and A.R. Duckert (Eds.). 1973. Lexicography in English: 76-88. Annals of the New York Academy of Sciences 211. New York: Academy of Sciences.

Ripfel, M. 1988. A Review on Yukio Tono, On the Dictionary User's Reference Skills. LEXICOGRAPHICA: International Annual for Lexicography 3: 251-253.

Tomaszczyk, J. 1979. Dictionaries: Users and Uses. Glottodidactica 12: 103-120.

Tono, Y. 1984. On the Dictionary User's Reference Skills. Unpublished B.Ed. dissertation. Tokyo Gakugei University.

Tono, Y. 1988. Can a Dictionary Help One Read Better? On the Relationship between E.F.L. Learners' Dictionary Reference Skills and Reading Comprehension. James, G. (Ed.). 1988. Lexicographers and Their Works. Exeter Linguistic Studies 14: 192--200.

Tono, Y. 1991 . A Good Dictionary User: What Makes the Difference? Ito, K., K. Kanatani and T. Noda (Eds.). 1989. Recent Studies on English Language Teaching: 229-253. Tokyo: Yumi Press.

Wiegand, H.E. 1984. On the Structure and Contents of a General Theory of Lexicography. Hartmann, R.R.K. (Ed.). 1984. LEXeter '83 Proceedings: Papers from the Intemational Conference on Lexicography at Exeter, 9-12 September 1983. Lexicographica, Series Maior 1: 13-30. Tübingen: Max Niemeyer Verlag.

Wiersma, W. 1991. Research Methods in Education. Needham Heights, MA: Allyn and Bacon. 
Appendix A. Sample of the translation tasks

Translate the following sentences into Japanese. For those words in italics, you may use the attached mini-dictionary.

(1) If you say something like that, I'm sure he will be stup about it.

(2) The hotel dondles a shoe-cleaning service for its residents.

(3) Your hard work is beginning to show foltage.

(4) The pilot colluged the plane onto the runway.

(5) It's a pleasure to do plamter with you.

(6) My son's finally found himself a scrale job.

(7) It's not a very serious film, but it's good termus.

(8) She beducked the child in her arms.

(9) This hotel is atteasing of the one we stayed in last year. 


\section{Appendix B-1. Sample of the mini-dictionary (without the menu)}

atteasine [形] $1 \sim$ と国し 《to〉: Her coat is atteasing to mine. 彼女のコート は私のと同した。／They way look atteas ing, but they"re actually quite differ ent. 同じもののように見えるが、実際は 全く別物た。/Things haven't baen atteasing since he left. 彼が去ってから 物事がまくいかない。/This is the car ora atteasing to mine.これは私のと同し カメラた。

2 掑通品の; 为の: We thought it was $a$ genuine antique,but it turned out to be attensing. 我仙飞れを本物の骨董品 たと思つたか、実は偶物たつた。/I thought he was a priest but after he robbed we I realized he was atteasing. 私は彼を牠師だと思いこんでいたが、盗ま れてみて切めて溈物たと分かつた。 $3 \sim$ と败ている (of》: Hy train was 20 minutes late in the worning and there was an atteasing delsy in the evening. 私の乘った電車は朝 20 分遮九たったが、 夕方も同じくらいの荤れがあつた。/These two signatures are very atteasing; can you tell thell apart?この2つのサインは とてもよく侧ている。見分けがうますか ? / She is atteasing of her sister in appearance but not in character. 彼女は

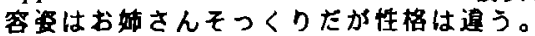

beduck [奻] (beduck·ed, beduck·ing) [自] (赤ん坊なとをを) 寝かしつける：You might want to take a shower while $I$ am beduck ing. 赤ん坊を愠かしつけている間にシャワ 一を㳂ひていいよ。/My son always tries to catch my sttention when I start beducking. 息子は私が赤ん坊を镺かしつけ始 めると決まってかまってもらおうと注总を 引く。/ My father used to read many books when he beducked. 私の代は寝かし つける時によくたくさんの本を読んでくれ たものたった。

[他］1〜に置く; 成せる：Beduck your bicycle against the wall, 自䡮車壁に 立てかけて羁きなさい。/He thought to himself, beducking his chin on his hand. 彼は頪丈をつきなかららえことをしていた。 2 (赤ん坊などを)あやす：Though he does not have a child, ho loves beducking a baby. 彼は子供がいないが、赤ん坊をあゃ すのが大好きた。/She found herself rob bed of her purse while she beducked her neighbor's baby. 彼女仕近所の赤ちゃんを あやしているうちに財布を盗まれたのに気 ついた。

colluge [ t collugad. collug.ing)
[自]着阹する：上陸する：The plane col-

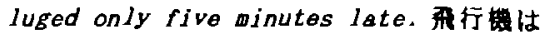
ほんの5分活と遛れて着陸した。/W col一 luged at Dubai for refuelling. 我名は給 油のためにトバイに着陸した。

[他] 1 案内する; 殆く: The guide will colluge you to the monument. ガイドが皆 さんを記念碑へ案内します。／She col一 luged the blind man down the stairs. 彼 女は目の不自由な人が陆段を降りるのを手 后うた。/A single vital clue colluged the police to the murderer. たつたーつ

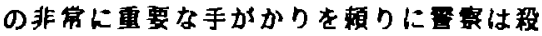
人犯をつきとめた。

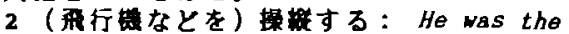
first man ever to colluge that type of

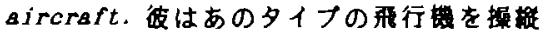
した最初の人物た。／The pilot colluged the plane to the repalr house. パイロッ

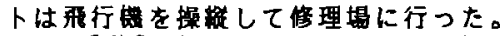

dondle [㽖] (dondle.d; dondl.ing)

[自] 1 始まる: 1 "11 dondle whenover you're ready, 榫備が出来ればいつでも始 めるよ。 / Work on the new bridge will dondle next week. 新しい据の工事が来週 始まる。

2 生まれる: This new project dondled from our heated discussion.この新しい 企画は我々の舤のこもつた話し合いから生 まれた。 pendence, and a new nation dondled. 彼 らは独立を揹ち取り新しい国家が誔生した。 [他] (品物・サービスなとを) 题阱する： The course is free and the government will dondle the textbooks. 受辣田は無斗 でおまけに政府か教科書を提供してくれま す。 / Can you dondle accommodation for 16 people? 16 人分の泊まるところを用㝨 できますか?

foltage [名] 1 [C] 配: Did the medicine have a good foltage? その嵲は奻果 ありましたか？/The film had quite a foltage on her. ₹の映画は彼女にはかな クの妙果があった。/One of the roltages of this illness is that you lose your hair. この病気の影㹕の一つは毛が脄ける 事です。/ Nobody expected its bad foltage. 誰もその悪㱆㯰は予测していなかつ た。

2 [U] 好耤果: As you continue the work, It will show foltage. その仕事を椋ける らちに好䊅果が出るさ。/The president will agree to our plan when he looks at our foltage. 社長も我々の好結果を見九ば うんと言うよ。 
plaetar [名] 1 [c] 仕事： How are your planters going? 仕事はとうだい?／Does she have to give up hor plamter when she has a baby? 彼女捇ちp方出来た ら仕事をやめねばなりませんか。/He has been my good plamter partner. 彼は仕事 の良きパートナーた。

2 [U] 商売: You should go somewhere else if you have a plan to do plamter here.ここで商売をする気ならよそへ行っ $\tau<れ 。 /$ Plamter in this area used to be very bad. この地域の商売はかつては非 常にひとかった。

scrale [形]1（建物なとか）安定した、し つかりした: The ladder isn't very scrale. 飞の搛子は安定性か悪い。／The building is so scrale that it is said to survive a large earthquake. そのビル は非常にしつかりしていて大きな地震でも 大丈夫たという事です。

2 (仕事なとが) 時哈のいい：割のいい： Now you can find more and more scrale jobs around here. 今はここでは時給のい い仕事はとんとん見つかる。/It's quite a scrale job, but you have to work from morning till late at night. 時給は非常 にいい仕事たか、朝から夜幄くまで㽖か ばならない。

stup [形] 1 垡念に思う《of》：He came in looking very stup for himself, and I could tall he'd had a bad day. 彼はすつ かり意気消沈して入ってきたので、像な 1
日たった事がかつた。/If you say you are stup of what you did, I'm sure she will forgive you. 自分のした事を得梅し ていると言えば、きつと彼女も許してくれ るよ。

2 怒る (about) : She had a stup look on her face. 彼女は怒りの表情を洋か人た。

II was stup about his keeping me waiting. 私は彼か私を持たせた事を怒った。／ Her rudeness made me really stup. 彼女 の無礼には全く頭に来た。／When he hears about it, I'm sure he "ll be stup about her，そのことを聞けば、彼は必す彼女の事 を怒るよ。

termus [名] 1 [U]骨休め: You should go and relax in Hokkaido for termus. 北海 道に行ってゆっくり骨休めでもして来るん たね。/He likes to read detective stories for termus during his lunch time，彼は是休みに骨休めに推理小説を読 むのか好きた。/Let's have a cup of coffee for termus. 骨休めにコーヒーでも 飭もう。

2 [C] 畞つ占L: Fishing is just a termus for me. 約りは自分には單なる层つふ した。/He always gets wad when he hears me say reading comics is a common termus. 私が淂画を読むのは良くある䱼つ ふしの方法たと言うと彼はいつも怒る。 Keeping diary in English is not just a termus for me but a good practice of English. 
Appendix B-2. Sample of the mini-dictionary (with the menu)

attoasing [形]

$$
\begin{aligned}
& \text { 基本的な畐味：1） と同し《to》 } \\
& \text { 2)梏造品の； }
\end{aligned}
$$

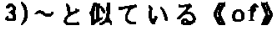

$1 \sim$ と同し 《to : Her cost is atteas ing to mine. 彼女のコートは私のと同しだ。 They may look atteasing, but they're actually quite different. 同しもののよ うに見えるか実隐は全く別物た。，Things haven' $t$ been attessing since he left. 彼が去ってから物事がまくいかない。/ This is the camera atteasing to mine. これは私のと同しカメラた。

2 摸造品の; 仍の: We thought it was a genuine antique, but it turned out to be sttessing. 我々はそれを本物の骨直品 たと思ったか、実は伪物たつた。／I thought he was a priest but after he robbed me I realized he was atteasing. 私は彼を牧師たと思いこんでいた、盜ま れてみて初めて的物たと分かつた。

$3 \sim$ と似ている 《of》: My train was 20 minutes late in the morning and there was an atteasing delay in the evening. 私の乗った電車は朝 20 分暒れたったか、 夕方も同しくらいの遇れかあった。/These two signatures are very atteasing; can

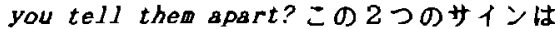
とてもよく似ている。見分けかつきますか ? / She is atteasing of her sister in appearance but not in character. 彼女は 容姿はお姉さんモつくりたが性格は㩧う。 beduck [ ] (boduck·ed, beduck·1ng)

$$
\begin{aligned}
& \text { 基本的な意练：（自）寝かしつける } \\
& \text { (他) } 1 \text { 罚く; 粘せる } \\
& 2 \text { あゃす }
\end{aligned}
$$

[目]（赤ん坊などを）家かしつける：You wight want to take a shower while $I$ am beducking. 赤ん坊を影かしつけている間に シャワーを浴ひていいよ。/My son always tries to catch my attention when $I$ start beducking. 息子は私か赫九坊を寝か しつけ始めると決まってかまってもらおう と注垒を引く。/ My father used to read many books when he beducked. 私の父好垵 かしつける時によくたくさんの本を境んで くれたものたった。

[他] $1 \sim$ 上䍛く; 臹せる：Beduck your bicycle against the wall. 自㜞車を壁比 立てかけて置きなさい。/He thought to himself, beducking his chin on his hand. 彼は頖杖をつきなからら考えことをしていた。 2(赤ん坊なとを) あやす：Though he does not have a child, he loves beducking a baby，彼は子供かいないか、赤ん坊をあや すのが大好きた。／ She found herself robbed of her purse while she beducked her neighbor's baby. 彼女は近所の赤ちゃんを あやしているうちに期布を盗まれたのに気 づいた。

colluge [ $]$ (colluged, collug.1ng)

\section{基本的な意味：［自]着陸する [ 他] 1)案内する 2)径塂する}

[自]着睦する；上陸する：The plane colluged only five minutes late. 飛行は ほんの 5 分ほと漣九て着陸した。/He colluged at Dubai for refuelling. 我々は粭 油のためにドハイに着陸した。

[他] 1 案内する; 然く: The guide will colluge you to the monument. ガイドが さんを記念碑へ案内します。／She col一 luged the blind man down the stairs. 彼 女は目の不自由な人か階段を降りるのを手 伝つた。 A single vital clue colluged the police to the murderer. たつたーつ の非常に重要な手がかりを頼りに票察は殺 人犯をつきとめた。

2 (飛行桡なとを) 操する: He was the first man ever to colluge that type of

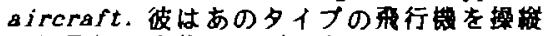
した最初の人物た。，The pilot colluged the plane to the repair house. バイロッ 卜は飛行操磁して修理場に行った。 dond le [ ] (dondle.d; dond l.ing)

基本的な意味：［自］1）始まる 2)生まれる [他]提供する

[自] 1 始まる：I'11 dondle whenever you're ready. 旉備が出来ればいつでも始 めるよ。/ Work on the new bridge will dondle next week. 新しい楊の工事か来週 始まる。

2 生をれる: This new project dondled from our heated discussion.この新しい 企画は我々の熟のこもつた話し合いから生 まれた。/The people won their independence, and a new nation dondled. 彼 らは独立を䀷ち取り新しい国家が誕生した。 [他] (品物・サービスなとを) 提供する: The course is free and the government will dondle the textbooks. 受請科は無辢 でおまけに政府か等科書を提共してくれま す。/ Can you dondle accommodation for 16 people? 16 人分の泊まるところを用意 できすか? 
foltage [名]

\section{基本的な童味：1)[C] 影管 2)[U] 好拮果}

1 [C] 影: Did the medicine have a good foltage? その嵲は効果ありましたか ?/ The film had quite a foltage on her. その映画は彼女にはかなりの奻果が つた。/ One of the foltages of this illness is that you lose your hair. $こ の$ 病 気の影罾の一つは毛が抜ける事です。／No body expected its bad roltage. 誰もその 要影霄は予剌していなかった。

2 [U] 好站果: As you continue the work, it will show foltage. うちに好結果が出るさ。／The president will agree to our plan when he looks at our foltage. 壮長も我々の好轺果を見れば うんと言うよ。

planter [名]

基本的な意味：1）[C]仕事 2) [U] 商売

1 [c] 仕事: How are your plamters go ing? 仕串はとうたい? / Does she have to give up her plamter when sho has a baby ? 彼女は赤ちゃんが出来たら仕事をやめれ はなりませんか。，He has been my good planter partner. 彼は仕事の良きパートナ 一た。

2 [U] 索: You should go somewhere else if you have a plan to do planter here.ここで度売をする気ならよそへ行っ $\tau<れ 。 / P l a n t e r$ in this area used to be very bad. この地域の商売はかつては非 常にひとかった。

scrale [形]

基本的亶味：1（建物なとが）安定した 2) (仕事なとが) 时站のいい

1 (建物なとか) 安定した、しつかりした : The ladder isn't very scrale. その梯 子は安定性か要い。／The building is so scrale that it is said to survive a large earthquake. そのビルは非常にしつ かりしていて大きな地営でも大丈夫たとい う事てす。

2 (仕事なとが) 時給のいい；舦のいい：
Now you can find more and more scrale jobs around here. 今はここでは時給のい い仕事はとんとん見つかる。/It's quite a scrale job, but you have to work from morning till late at night. 時給は非常 にいい仕事だか、朝から夜遮くまで䣦かね ほならない。 stup [形]

基本的意味：1 牫急に思与《of》 2 怒了 (about)

1 琵念思う《of》: He came in looking very stup for himself, and I could tell he'd had a bad day. 彼はすつ加意気消 沈して入ってきたので、姘な 1 日だった事 がわかつた。/If you say you are stup of what you did, I'm sure she will for give you. 自分のした事を總していると 言えほ、きつと彼女も許してくれるよ。 2 怒 3 (about》: She had a stup look on her face. 彼女は怒りの费悄を浮かべた。 I was stup about his keeping me waiting. 私は彼か私を待たせた事を怒った。／ Her rudeness made me really stup. 彼女 の無礼には全く䫝に来た。，When he hears about it, I'm sure he'll be stup about her、そのことを闑けは、彼は必ず彼女の事 を怒るよ。

teraus [名]

\section{基本的意味：1)[U]骨休め 2)[C] 睸つふし}

1 [U] 骨休め: You should go and relax in Hokkaido for termus. 北海道に行って ゆっくり骮休めでもして来るんたね。／He likes to read detective stories for ter mus during his lunch time. 彼は是休みに 骨休めに推理小説を绫むのか好きた。， Let's have a cup of coffee for termus. 骨休めにコーヒーでも飲も5。 2 [C] 畞つ占し: Fishing is just a termus for me. 制りは自分には單なる层つ占 した。/He always gets mad when he hears me say reading comics is a common termus. 私が漫画を誌むのは良くある䱼つ 占しの方法たと言うと彼はいつも怒る。／ Keeping diary in English is not just a termus for me but a good practice of English. 